\title{
A review of mining taxes in Africa: Tax burden, the strength of democratic systems and levels of corruption
}

\begin{tabular}{|c|c|}
\hline \multicolumn{2}{|c|}{ 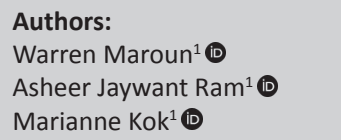 } \\
\hline \multicolumn{2}{|c|}{$\begin{array}{l}\text { Affiliations: } \\
{ }^{1} \text { School of Accountancy, } \\
\text { University of the } \\
\text { Witwatersand, } \\
\text { Johannesburg, South Africa }\end{array}$} \\
\hline \multicolumn{2}{|c|}{$\begin{array}{l}\text { Corresponding author: } \\
\text { Warren Maroun, } \\
\text { warren.maroun@wits.ac.za }\end{array}$} \\
\hline \multicolumn{2}{|c|}{$\begin{array}{l}\text { Dates: } \\
\text { Received: } 18 \text { Oct. } 2018 \\
\text { Accepted: } 29 \text { Aug. } 2019 \\
\text { Published: } 31 \text { Oct. } 2019\end{array}$} \\
\hline \multicolumn{2}{|c|}{$\begin{array}{l}\text { How to cite this article: } \\
\text { Maroun, W., Jaywant Ram, } \\
\text { A., \& Kok, M. (2019). A } \\
\text { review of mining taxes in } \\
\text { Africa: Tax burden, the } \\
\text { strength of democratic } \\
\text { systems and levels of } \\
\text { corruption. South African } \\
\text { Journal of Business } \\
\text { Management, 50(1), a941. } \\
\text { https://doi.org/10.4102/ } \\
\text { sajbm.v50i1.941 }\end{array}$} \\
\hline \multicolumn{2}{|c|}{$\begin{array}{l}\text { Copyright: } \\
\text { (c) 2019. The Authors } \\
\text { Licensee: AOSIS. This } \\
\text { is licensed under the } \\
\text { Creative Commons } \\
\text { Attribution License. }\end{array}$} \\
\hline \multicolumn{2}{|l|}{ Read online: } \\
\hline 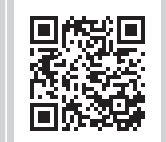 & $\begin{array}{l}\text { Scan this QR } \\
\text { code with your } \\
\text { smart phone or } \\
\text { mobile device } \\
\text { to read online. }\end{array}$ \\
\hline
\end{tabular}

Background: This article examines features of the tax systems of 19 African countries with material mining operations.

Objectives: An interpretive approach is used to explore the implications of a country's commitment to democracy (according to the Economist Intelligence Unit) and perceived levels of corruption (according to Transparency International) for the tax burden experienced in some of Africa's mining industries. The scores are contrast with the strength of the jurisdictions' democratic systems and levels of corruption.

Method: Income tax rates, the number of taxes charged and the administrative challenges experienced by taxpayers are used to calculate a composite 'tax burden score' for each country. The scores are compared with the levels democracy and corruption reported by the Economist Intelligence Unit and Transparency International respectively.

Results: Results suggest that democracies are just as capable of extracting value from taxpayers as authoritarian regimes where legal or electoral challenges to unfair tax policy are less likely. Authoritarian governments do not, however, always have the highest tax rates. Free from the need to invest in democratic systems and social welfare, taxes are levied at a lower rate than in more democratic countries. Taxpayers are, however, more likely to experience administrative challenges when applying the applicable tax laws than would be the case under democracy. The result is a trade-off between value extracted directly in the form of tax and compliance or other regulatory costs.

Conclusion: These findings make an important contribution to the tax literature by providing a multi-jurisdictional analysis of tax practice in a seldom-studied context. From a practical perspective, the findings can also inform the tax planning, risk management and reporting practices of organisations with material mining investments in Africa.

Keywords: Corruption; democracy; mining tax; tax; tax burden.

\section{Introduction}

Africa has enormous economic potential. The continent boasts significant natural resources and a young population which is expected to double in the next 25 years. Importantly, it is the only region where the size of the workforce is expected to grow beyond 2035 and where an exponential increase in urban development and industrialisation is still possible (World Economic Forum, 2017). Africa is also a paradox. Its wealth in natural and human capital is offset by severe poverty, low levels of education and a crumbling health care system (Monks, 2018; Patrick, 2012). There are some examples of significant policy and industrial capacity development but Africa continues to lag behind developed nations in terms of productivity and competitiveness (World Economic Forum, 2017). There are many reasons for this but one aspect of Africa's stunted development which is of interest for the purpose of this research is weaknesses in the continent's democratic systems and high levels of corruption.

A 2017 report by the Economist Intelligence Unit (EIU) shows that only Mauritius is a full democracy, while Transparency International (2016) finds that several African states report some of the highest incidences of corrupt practices and behaviour in the world. The combined effect of corruption and a lack of commitment to democracy are expected to have implications for tax regimes in Africa.

Companies have devoted considerable attention to managing tax-related risks (Segal, Segal, \& Maroun, 2017) but punitive tax rates, the number of taxes being levied and the administrative 
difficulties encountered when engaging with the relevant authorities result in a high tax burden. This, in turn, poses significant challenges for investing and managing ventures in Africa (PwC, 2017a, 2017b). While a number of factors contribute to the development and application of tax policy, the burden experienced by taxpayers may be influenced by weaknesses in democratic systems (Cheibub, 1998; Ehrhart, 2011; Huňady \& Orviská, 2015). For example, flawed electoral processes, a biased judiciary and the absence of a free press can make it difficult to hold government accountable and challenge tax policy. This may be the case, even if existing regulations and practice result in an undue burden on the taxpayer (Cheibub, 1998). Weak democratic systems may also contribute to higher levels of corruption. While the checks and balances necessary for protecting citizens fail, misappropriation of resources, wasteful government expenditure and a breakdown in essential services are more likely (Transparency International, 2017a,b, 2018). In this environment, it is more difficult for taxpayers to challenge unfair tax policy or practice while a loss of state revenue may drive taxes even higher.

With this in mind, an exploratory research design is used to examine the interconnection between the strength of democratic systems and levels of corruption, on the one hand, and the tax burden experienced by taxpayers on the other hand. Income tax rates, the number of taxes charged and the administrative challenges experienced by taxpayers are used to construct a composite 'tax burden score'. This is contrasted with the EIU's democracy index (DI) (The Economist, 2017) and the perceived levels of corruption reported by Transparency International $(2017 a, b)$.

The study focuses specifically on the mining industry. Nineteen African countries with significant international investment in mining operations are examined. Dealing only with the mining taxes controls for variations in tax policies from industry to industry. The decision to examine how African governments tax mining companies are also informed by the significant contribution which mining makes to the gross domestic product (GDP) and national revenues of those countries with established mining operations (PwC, 2017a, 2017b).

The research makes an important empirical and theoretical contribution by adding to the relatively limited body of work on the differences in mining tax regimes in Africa (Grose \& Koryakovtseva, 2017; Stevens, 2017; Woods \& Lane, 2015). While different aspects of African corporate governance and reporting have been examined to some extent (see, e.g. Atkins \& Maroun, 2015; Armstrong, Segal, \& Davis, 2005; Ntim, Opong, Danbolt, \& Thomas 2012), there is little on tax policy and practice on the continent. Much of the prior research is also concerned with studying a single jurisdiction rather than comparing policies and practices of different countries. At the same time, the impact of democracy and corruption on government revenue has been considered (see Ehrhart, 2011; Huňady \& Orviská, 2015; Jetter, Agudelo, \&
Hassan, 2015), but the implications of weaknesses in democratic systems and higher levels of corruption for the burden experienced by taxpayers are not specifically addressed. Finally, in terms of risk management practices, this research shows that companies cannot focus exclusively on tax risk at the transactional or compliance level. Tax risk can be affected by the broader socio-political context and this should be quantified and taken into account in risk management policies when investing in different jurisdictions (see Elgood, Paroissien, \& Quimby, 2004; Segal et al., 2017).

The remainder of this article is structured as follows: The 'Democracy and corruption in Africa' section explains the chosen democracy and corruption indices. An outline of the tax systems in the selected African states is provided in the section 'Tax systems' and used to construct a relative tax burden measure. The 'Method' section deals with the method. Results are presented in the 'Results' section. The 'Discussion, conclusion and implications' section discusses key findings and areas for future research.

\section{Democracy and corruption in Africa}

A review of the sociological and political literature on the definition, characteristics and philosophy of democracy is beyond the scope of this research. A study on the effect of democracy on developing countries' tax revenues uses three measures of a country's democracy (Ehrhart, 2011). The first is Freedom House's country rankings according to political rights and civil liberties. Countries are assigned a score based on a subjective review of over 60 indicators by a panel of experts (Freeedom House, 2018). This is complemented by a binary regime classification as either democratic or authoritarian and a measure of the 'concomitant qualities of democratic and autocratic authority in governing institutions' (see also Cheibub, 1998; Cheibub, Gandhi, \& Vreeland, 2010). The latter measures authoritarianism ranging from hereditary monarchies (-10) to consolidated democracies (+10). According to the Centre for Systemic Peace (CSP), the scoring scheme:

... consists of six component measures that record key qualities of executive recruitment, constraints on executive authority and political competition. It also records changes in the institutionalized qualities of governing authority. (CSP, 2016:1)

The binary classifications are not only the least subjective but also minimalistic. Scores generated by Freedom House and the CSP are more detailed but incorporate more judgement and have been criticised for using an arbitrary process for aggregating scores (Cheibub et al., 2010; Treier \& Jackman, 2008). As a result, The EIU's Democracy Index is used to categorise political systems.

While the index may suffer from similar limitations to other democracy measures, it has a number of desirable features. Firstly, it relies on a scoring system that strikes a balance between an oversimplifying dichotomous scale and more complex scoring techniques which are difficult to apply consistently. Secondly, while most democracy measures are 
based on expert opinion (Cheibub et al., 2010), the EIU includes a number of public surveys to refine and calibrate the results from expert reviews (The Economist, 2018). Features pointing to a strong culture of democracy include, in no particular order:

- electoral process and pluralism - whether or not elections take place regularly for different levels of government, are free and fair and subscribe to the principle of universal suffrage

- civil liberties - freedom of expression and the absence of a fear of reprisal for holding different political views

- the functioning of government - duly elected officials should be responsible for developing government policy and there should be safeguards over the exercise of a government's authority

- political participation - the extent to which the adult population (including both genders and minority groups) engage in the political process

- political culture - citizens' perceptions about democratic rule as opposed to authoritarian systems (The Economist, 2017, pp. 66-75).

Based on an assessment of the above features, the EIU generates a score or DI ranging from 0 to 10 which is used to categorise counties as full democracies, flawed democracies, hybrid regimes or authoritarian regimes (The Economist, 2018). Table 1 explains the categories in more detail.

The EIU uses the democracy indices and country categorisations to 'provide a snapshot of the state of democracy for 165 independent states and two territories' and give a sense of how the five features of democratic systems change over time (The Economist, 2018). Focusing specifically on Africa, the EIU finds that in sub-Saharan Africa, electoral processes and political culture have improved over the last 5 years but have been offset by a decline in civil liberty and several functional or governance challenges. Elections in this part of the world take place regularly and, in many cases, are free and fair (Chatham House, 2017; Maendeleo Policy Forum, 2016). However, 'the regional score for electoral processes has remained persistently low, reflecting a lack of genuine pluralism in most countries' (The Economist, 2017, p. 32). Only 11 out of the 44 surveyed African countries reported improvements in their democracy indices from 2015 to 2017 and 25 deteriorated (The Economist, 2017).
Unsurprisingly, high levels of corruption and misuse of state resources usually accompany anti-democratic behaviour (Hollyer \& Wantchekon, 2011; Kong, 2004). Democracy does not guarantee the absence of corruption but can contribute to lower levels of corruption because of the emphasis placed on transparency, good governance and the role of citizens in holding elected officials accountable (Kolstad \& Wiig, 2016; Kubbe \& Engelbert, 2018). In this context, countries ranked worse for corruption in a survey by Transparency International (2016) are characterised by weak or dysfunctional public institutions and ineffective control systems in the private and/or public sector (Rose-Ackerman, 2004; Transparency International, 2018). This is especially true when traditional accountability mechanisms - such as civil society, government auditors or the press - are unable to function independently or without fear of reprisal (Transparency International, 2016, 2017a,b).

Table 2 shows the type of government, DI and perceived levels of corruption in the 19 African states under review. The DI is computed by the EIU and the corruption scores are those reported by Transparency International. The latter are

TABLE 2: Country by government type, democracy index and perceived level of corruption.

\begin{tabular}{llcl}
\hline Country & Government type & DI & Cl \\
\hline Algeria & Authoritarian & 3.56 & 34 \\
Angola & Authoritarian & 3.62 & 18 \\
Benin & Hybrid regime & 5.61 & 36 \\
Botswana & Flawed democracy & 7.81 & 60 \\
Burkina Faso & Hybrid regime & 4.75 & 42 \\
Côte d'lvoire & Authoritarian & 3.93 & 34 \\
Ghana & Flawed democracy & 6.69 & 43 \\
Kenya & Hybrid regime & 5.11 & 26 \\
Mali & Hybrid regime & 5.64 & 32 \\
Mozambique & Hybrid regime & 4.02 & 27 \\
Namibia & Flawed democracy & 6.31 & 52 \\
Nigeria & Hybrid regime & 4.44 & 28 \\
Senegal & Flawed democracy & 6.15 & 45 \\
South Africa & Flawed democracy & 7.24 & 45 \\
Tanzania & Hybrid regime & 5.47 & 32 \\
The Democratic Republic of Congo & Authoritarian & 1.61 & 21 \\
\hline Uganda & Hybrid regime & 5.09 & 25 \\
Zambia & Hybrid regime & 5.68 & 38 \\
Zimbabwe & Authoritarian & 3.16 & 22 \\
\hline Note: & & & \\
\hline
\end{tabular}

Note: Please see the full reference list of the article, Maroun, W., Jaywant Ram, A., \& Kok, M (2019). A review of mining taxes in Africa: Tax burden, the strength of democratic systems and levels of corruption. South African Journal of Business Management, 50(1), a941. https://doi.org/10. 4102/ sajbm.v50i1.941, for more information.

$\mathrm{DI}$, democracy index; $\mathrm{Cl}$, corruption index.

TABLE 1: Categories of political systems.

\begin{tabular}{|c|c|c|}
\hline Type of government & Democracy index & Description \\
\hline Full democracy & $\mathrm{DI}>8$ & $\begin{array}{l}\text { Basic political freedoms are respected. There is a strong democratic culture with few legal, political or institutional challenges and } \\
\text { no material threat to democratic processes and systems. }\end{array}$ \\
\hline Flawed democracy & $6<\mathrm{DI} \leq 8$ & $\begin{array}{l}\text { There are free and fair elections and citizens' liberties are respected but the political system is weakened by low participation in the } \\
\text { political process, governance challenges and voters' perception of the effectiveness of their democracies. }\end{array}$ \\
\hline Hybrid regime & $4<\mathrm{DI} \leq 6$ & $\begin{array}{l}\text { While there are elections, these are characterised by material flaws or irregularities. The weaknesses characterising flawed } \\
\text { democracy are more prevalent. Corruption is common and institutions (such as the judiciary, the press or civil rights groups) are } \\
\text { not independent or supported. }\end{array}$ \\
\hline
\end{tabular}

Source: The Economist: Transparency International (2017a). Sub-Saharan Africa: Corruption is a big issue in 2016 African elections. Retrieved from https://www.transparency.org/news/feature/ africa_corruption_is_a_big_issue_in_2016_african_elections

DI, democracy index. 
determined in a similar way to the democracy indices. The index is based on data sourced from 13 different institutions and expert assessments and used to gauge the perceived levels of corruption in the public sector. ${ }^{1}$ Scores range from 0 (very corrupt) to 100 (clean) (Transparency International, 2018).

It is difficult to quantify the precise effect of weaknesses in democratic systems on the cost associated with corruption (Kubbe \& Engelbert, 2018). Nevertheless, Transparency International (2018, p. 6) concludes that, in general, 'beating corruption is crucial to healthy democracy' with none of the full democracies identified by the EIU reporting higher levels of perceived corruption. Focusing specifically on the 19 African countries listed in Table 2, flawed democracies have an average DI and perceived corruption index (CI) of 6.84 and 49.00 , respectively. This is in contrast with hybrid regimes where the mean DI falls to 4.39 and the average $\mathrm{CI}$ drops to 31.78. Authoritarian regimes fare worst with an average DI and CI of 3.03 and 25.80, respectively.

\section{Tax systems}

Mining companies are subject to unique tax treatment in jurisdictions around the world (Extractive Industries Transparency Initiative, 2009) usually on the grounds that their operations are different from other economic activities (Otto et al., 2006) or give rise to material, social and environmental impacts (Carels, Maroun, \& Padia, 2013) which justify an additional charge by the state (Extractive Industries Transparency Initiative, 2009). The imposition of a type of super or extraction-linked tax has also been defended on the basis that mineral resources belong to a country's citizens and that mining companies should be required to pay for mineral extraction as part of a long-term contribution to society (Otto et al., 2006). For many African governments, this view is linked to the fact that the colonial system dispossessed indigenous people of their mineral wealth. In this context, taxes on the mining sector become part of socio-political policies designed to address the effects of colonialism in addition to being seen as a source of national income (see, e.g. Maroun, Turner, \& Sartorius, 2011; Mitchell, 2009; Mkandawire, 2010).

\section{Overview of tax systems}

This article focuses specifically on differences in income tax regimes (as the primary form of tax imposed on mining houses). In very broad terms, these are calculated based on a measure of total income less allowed deductions that may or may not include different capital costs incurred to

1.These include: (1) the African Development Bank Country Policy and Institutiona Assessment (2016), (2) Bertelsmann Stiftung Sustainable Governance Indicators (2018), (3) Bertelsmann Stiftung Transformation Index 2017-2018, (4) the Economist Intelligence Unit Country Risk Service (2018), (5) Freedom House Nation in Transit (2018) (6) Global Insight Business Conditions and Risk Indicators (2017) in Transit (2018), (6) Global Insight Business Conditions and Risk Indicators (2017) (7) the IMD World Competitiveness Centre World Competitiveness Yearbook Executive Opinion Survey (2018), (8) Political and Economic Risk Consultancy Asian Intelligence (2018), (9) the PRS Group International Country Risk Guide (2018), (10) the World Bank Country Policy and Institutional Assessment (2017), (11) the World Economic Forum Executive Opinion Survey (2018), (12) the World Justice Projec Rule of Law Index Expert Survey (2017-2018) and (13) Varieties of Democracy (V-Dem) 2018. develop, operate or decommission a mine (Sunley \& Baunsgaard, 2001, p. 3). The research also focuses on royalty charges because of their extensive use in the sector (EY, 2017).

Royalties are designed to balance the risks involved in developing mineral resources between the extractor and resource owner (Otto \& Cordes, 2002) and ensure that the latter retains a fair share of the economic value generated by mining (Otto et al., 2006; Tsalik, 2004). According to Otto et al. (2006), royalty taxes can be seen as an instrument requiring the payment of compensation by an extractor to a state - in its capacity as the owner of a nation's minerals - in exchange for the permission to access and develop resources for economic benefits. In this way, the royalty payment is a type of ownership transfer tax rather than a tax on net income or proceeds from operations.

In addition to income tax and royalty charges, other taxes may be imposed such as customs and excise duty, valueadded taxes (VATs), withholding taxes and environmental taxes (Deloitte, 2018; PKF, 2017). These are treated as supplementary taxes because they are not based on mining companies' access to and extraction of minerals or profits generated from core operations. The income and royalty rates (taxes) levied by the selected African countries are summarised in Table 3. (Additional information is provided in Appendix 1.)

According to Table 3, the average income tax rate is 30\% with a maximum of $37.5 \%$ (Namibia) and minimum charge of $19 \%$ (Algeria). Zimbabwe (15\%) and Kenya (12\%) have the highest royalty tax rates that are levied on diamonds. Namibia and Botswana also have relatively high royalty taxes on diamonds and other precious stones (10\%). South Africa is the only jurisdiction where royalties are calculated based on the value of what is extracted rather than at a fixed rate. In addition to income taxes and royalties, supplementary taxes imposed in different African states are summarised in Table 4. (For details, see Crowe Horwath, 2016; Deloitte, 2018; PKF, 2017.)

According to Table 4, seven countries charge mining companies for a licence to commence and conduct their operations (PKF, 2017). Alternatively, a surface tax based on the area in which exploration or extraction is taking place is applied. In Angola, for example, the surface tax is calculated based on the area awarded to the taxpayer for mining purposes but only applies during the exploration phase (Fialho \& Viana, 2017; Sousa \& Moreira, 2016). Benin and Kenya make use of fix rights and area taxes that are, in substance, similar to a surface tax (PKF, 2017; Stevens, 2017). Only Benin, the Democratic Republic of Congo (DRC) and Senegal charge a license fee in addition to a surface or fix rights and area tax.

Côte d'Ivoire and Mozambique levy VAT on mineral and metal exports. The other 17 countries either exempt or zerorate these sales for VAT purposes (Deloitte, 2018; PKF, 2017) but, in Tanzania, an inspection fee of $1 \%$ of the value of all mineral exports has been imposed (Murphy, 2017). 

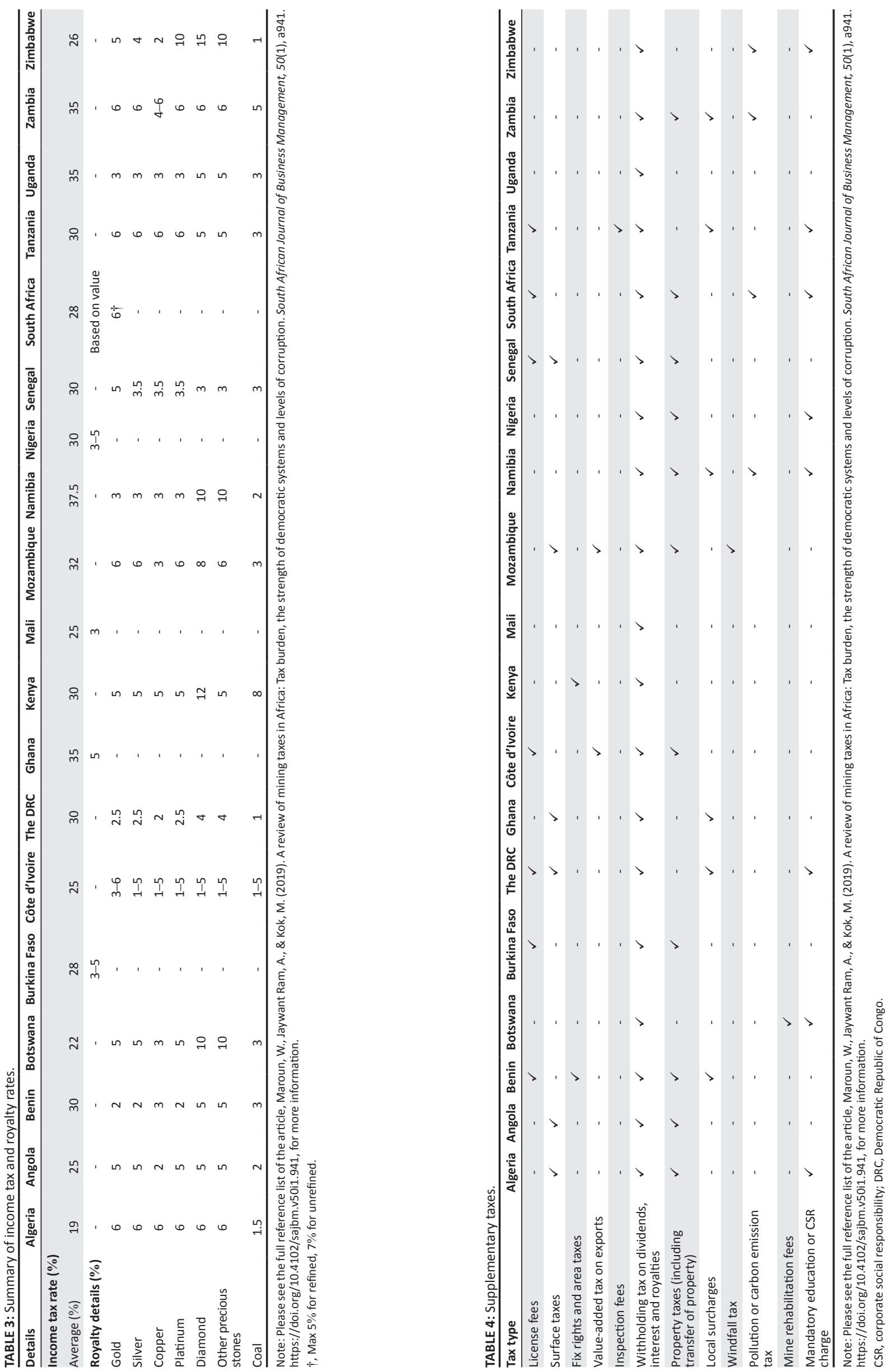
In all of the jurisdictions, companies paying dividends, interest or royalties to non-residents must levy withholding taxes (Deloitte, 2017b). Property taxes are also common. Eleven of the 19 jurisdictions apply taxes on property owned by corporates. Additional amounts are payable when transferring fixed property (Deloitte, 2017b; PKF, 2017).

Local surcharges are additional taxes on specific items and include, for example, the Tanzanian service levy surcharge (PKF, 2017), special import levies in Ghana (Crowe Horwath, 2016; PKF, 2017) and radio and television taxes in Benin (Deloitte, 2017b). In Mozambique, a 20\% windfall profits tax is levied where the pre-corporate income tax net return is in excess of $18 \%$ (Coimbra et al., 2017).

Pollution and carbon emission taxes are levied to reduce adverse environmental impacts and include, for example, the Namibian carbon tax (Deloitte, 2017b) and the Zambian environmental vehicle tax (PKF, 2017). Mine rehabilitation fees are payable in Botswana to provide for the cost of the rehabilitation of mines at the end of their useful lives (Deloitte, 2017b).

Finally, in addition to environmental-related taxes, eight jurisdictions have introduced education and corporate social responsibility (CSR) charges. Examples of the former include education, training and other skills development levies. In countries like Zimbabwe, an acquired immunodeficiency syndrome (AIDS) levy is applied, while South Africa requires mining companies to make investments in community development as part of the country's broader social agenda (Deloitte, 2017b; PKF, 2017).

\section{Gauging the tax burden in Africa}

To give a sense of the total tax burden (TTB) on mining companies in each African jurisdiction, a relative tax index is computed. The index is informed by the overriding requirement for tax to be charged only once and levied at a rate that does not compromise the taxpayer's long-term sustainability (Vivian, 2006). Related closely to this, the application of the respective tax laws should not result in undue administrative costs (Maroun et al., 2011; PwC, 2017). The following indicators are taken into account:

- the level of income tax

- the rate at which royalty taxes are charged

- the number of supplementary taxes

- an overall indication of administrative difficulties encountered by taxpayers when compiling and submitting their tax returns and engaging with the relative tax authority.

With these points in mind, income and royalty taxes need to be assessed on a relative basis. The rate of tax in each jurisdiction is expressed as a percentage of the maximum income tax or royalty rate applied by the 19 countries under review. For ease of analysis, where a range of income tax or royalty rates apply, the midpoint is used as an estimate of the average rate although this is an inherent limitation of the relative tax index. The result is an income tax ratio (ITR) and royalty tax ratio (RTR) for each country with a minimum value of 0 (indicating a low tax burden) and a maximum value of 1 (indicating a high tax burden).

Supplementary taxes are computed using different bases in each country and an absolute measure of the revenue collected for each tax per country is not available. These taxes can, however, result in a material charge for a company (Deloitte, 2017b) and increase the administrative costs of complying with the respective tax systems (PwC, 2017). To take the additional tax burden into account, the number of supplementary taxes per jurisdiction is expressed as a ratio of the maximum number of supplementary taxes in operation. The supplementary tax ratio (STR) ranges from 0 (low tax burden) to 1 (high tax burden).

Finally, PwC (2017) surveys tax experts in a number of jurisdictions to evaluate the overall difficulty experienced by taxpayers when ensuring compliance with tax regulations. The survey takes into account factors such as the complexity of individual taxes, uncertainty in the application of tax laws, time to comply with tax laws, number of tax payments, accuracy of assessments by tax authorities and the perceived stability of the tax system. A total of 190 countries are reviewed and ranked according to the degree of difficulty of working with the prevailing tax regime. To generate a tax difficulty ratio (TDR), the rankings of each of the 19 African states are expressed relative to the 190th position in the survey. A score tending to 1 indicates a challenging tax environment. The final tax burden score is determined as follows:

$$
\text { Total tax burden }(T T B)=\frac{I T R+R T R+S T R+T D R}{4}
$$

The TTB assigns equal weightings to the level of income taxes (ITR), the average royalty rates (RTR), number of taxes imposed on a company (STR) and degree of perceived difficulty working with the respective tax regime (TDR). It does not provide an econometric model for quantifying the total cost of imposed taxes (see Liu \& Altshuler, 2013) but it does give a useful tool for comparing African tax systems and exploring how government types and the level of corruption may affect the perceived tax burden.

\section{Method}

A detailed review of the technical tax literature and, where applicable, tax legislation was performed to identify key features of the mining tax regimes of selected African countries. Countries where material mining operations are not under way or where data on the tax systems are not available were excluded. This left 19 countries for review as shown in Tables 2 and 3.

As discussed in section 'Tax systems', normal tax rates and royalty charges (see Table 3) are used to compute the ITR and RTR for each African state. The number of taxes imposed in 
each jurisdiction (see Table 4) is used to determine the STR. The PwC (2017) rankings of tax systems provide a basis for the TDR. The TTB is then computed for each country. Variations in the TTB are interpreted in the context of prevailing political systems (according to The Economist, 2017) and levels of perceived corruption in each jurisdiction (according to Transparency International, 2017a,b).

Inferential statistical analysis was inappropriate because of the small sample size. The TTB, democracy (The Economist, 2017) and corruption indices (Transparency International, 2016) are also inherently subjective. To avoid creating the impression that these measures are scientifically determined and in keeping with this article's exploratory design - an interpretive approach is used to analyse the different tax systems (Brennan \& Solomon, 2008; Leedy \& Ormrod, 2014). The relationship between the TTB, DI and level of corruption for each country is presented graphically. Each country being studied is also organised in an easy-to-interpret $2 \times 2$ matrix that shows the level of tax burden versus the type of political system. For this purpose, countries with a TTB falling below the first and second quartiles of the final TTB scores are presented as having a relatively low tax burden. A TTB between the second and third quartiles is interpreted as a medium tax burden. Scores in excess of the third quartile signify a high tax burden. The political systems are those defined by EIU: flawed democracies, hybrid systems and authoritarian regime (The Economist, 2017). Levels of corruption (according to Transparency International, 2016, $2017 \mathrm{a}, \mathrm{b})$ are also taken into account as part of the analysis.

\section{Results}

Using the information from Tables 3 and 4 , the TTB is computed for each country. Results are presented in Table 5. Uganda reports the lowest tax burden (TTB $=0.52)$, while Nigeria has the highest score (TTB $=0.88$ ). The average TTB is 0.69 . Nine of the 19 countries have higher than average scores. These countries are not necessarily those subject to authoritarian rule. For example, Angola is classified as an authoritarian regime (The Economist, 2017) and has a TTB of 0.56 (which is one of the lowest TTB scores). In contrast, Namibia is categorised as a flawed democracy (The Economist, 2017 ) but has one of the highest TTBs (TTB $=0.79)$.

To make the data in Table 5 easier to interpret, it is represented diagrammatically together with the total corruption and democracy indices as shown in Table 2. These indices assign a higher score to democratic states and those with lower levels of corruption, respectively. The inverse of these indices is therefore computed to plot the relationship between the TTB, anti-democratic behaviour or existence of corrupt practices.

Figure 1 shows that, in general, as democratic systems break down, governments become more authoritarian (RoseAckerman, 2004; The Economist, 2017) and higher levels of corruption result (Rose-Ackerman, 2004; Transparency International, 2017a,b; Zaloznaya, 2015). For example, Algeria, Angola and Zimbabwe are classified as authoritarian regimes 


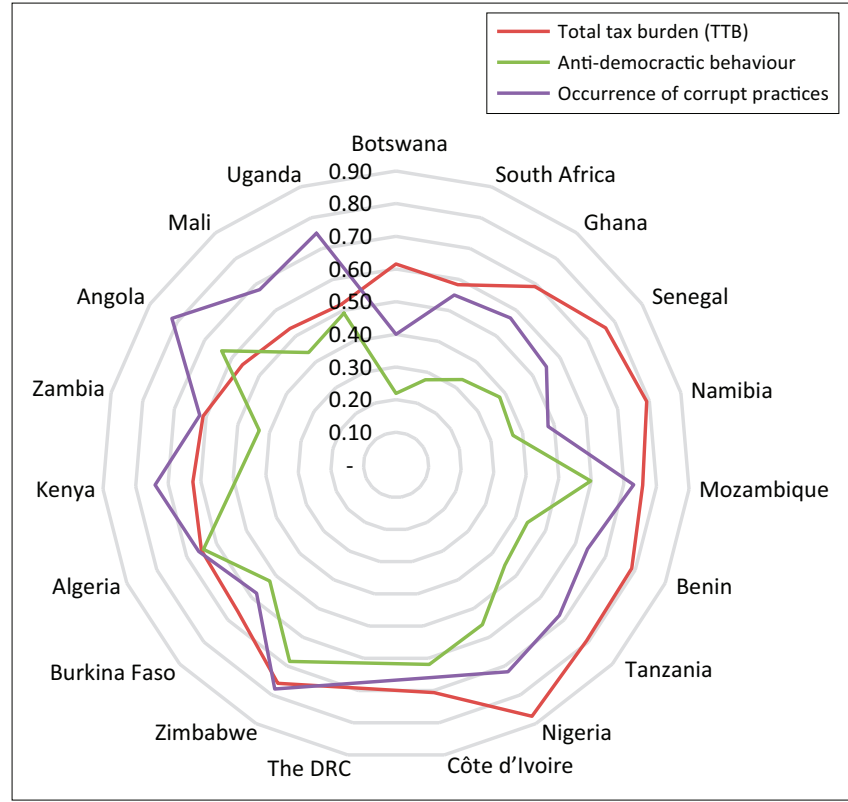

FIGURE 1: Democracy, corruption and tax burden.

(The Economist, 2017). They also have the highest levels of corruption of the 19 countries under review (Transparency International, 2017a,b). This is not to say that more democratic states are corruption-free. Mozambique and Nigeria, for instance, are hybrid regimes but report higher levels of corruption than Côte d'Ivoire and Algeria, two authoritarian regimes. Similarly, only Botswana scores above the global average for flawed democracies as per the Transparency International $(2017 \mathrm{a}, \mathrm{b}) \mathrm{CI}$.

The relationship between TTB, anti-democratic behaviour and higher levels of corruption is complex. For some countries, such as Zimbabwe and the DRC, corruption and authoritarianism are positively correlated with the TTB. In other instances (such as Angola and Algeria), anti-democratic behaviour and corruption are inversely related to the TTB. Similarly, some democratic states with relatively low levels of corruption (such as Botswana and Namibia) report high TTBs. To examine the relationship between the types of democratic system (flawed democracy, hybrid regime or authoritarian state) and the total TTB in more detail, the data are presented in matrix form (Figure 2).

South Africa and Botswana have a relatively low tax burden (TTB $=0.58$ and 0.61 , respectively). This cannot be attributed to efforts at economic diversification resulting in a reduced contribution to GDP and national revenue from mining. On the contrary, the South African and Botswanan economies are significantly dependent on the industry and derive approximately $38 \%$ and $91 \%$ oftheir export revenue, respectively, from the mining sector (Ericsson \& Löf, 2017). As a result, the countries have an above-average income tax rate $\left(\mathrm{ITR}_{\text {Botswana }}=0.80\right.$; $\left.\mathrm{ITR}_{\text {South Africa }}=0.75\right)$, reflecting the fact that the sector is an important source of tax revenue. They also levy royalties on the extraction of key minerals in line with other African states (Gajigo, Mutambatsere, \& Ndiaye, 2012).

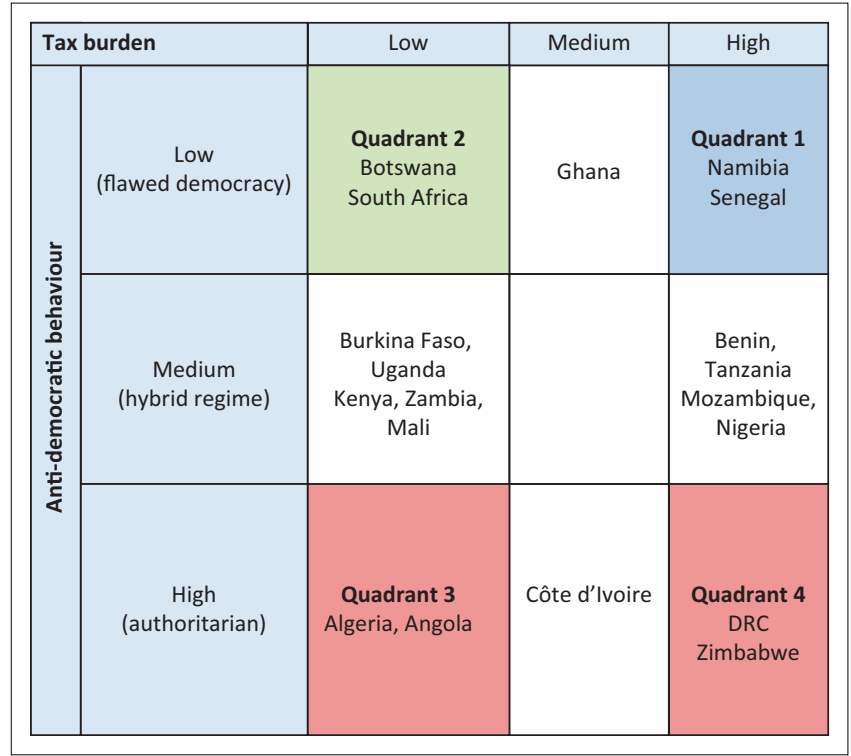

DRC, Democratic Republic of Congo.

FIGURE 2: Tax burden versus political system matrix.

The relatively high ITR and RTR scores are, however, offset by a significantly lower $\mathrm{TDR}\left(\mathrm{TDR}_{\text {Botswana }}=0.25 ; \mathrm{TDR}_{\text {South Africa }}=\right.$ $0.24)$. This suggests that taxpayers are benefitting from efficiencies in tax administration and due process (see PwC, 2017) rather than direct savings from low tax rates. The low TDR and TTB scores are also consistent with the fact that both countries are classified as flawed democracies (The Economist, 2017) but are among the most stable economies in the region (World Economic Forum, 2017) with relatively lower levels of corruption than other African countries (Transparency International, 2017a,b). Overall, the relationship between the low TTB and high democratic index suggests that these more mature democratic states emphasise the rights of taxpayers and the need for an efficient and fair tax system. This should be contrasted with countries positioned in Quadrant 4.

Like South Africa and Botswana, Zimbabwe and the DRC earn a significant portion of their foreign currency from mining and the sector makes a material contribution to GDP (Ericsson \& Löf, 2017). Compared to South Africa, Zimbabwe and the DRC are less diversified and developed. As a result, they rely on relatively higher income tax rates $\left(\mathrm{ITR}_{\mathrm{DRC}}=0.80\right.$; ITR $_{\text {Zimbabwe }}=0.69$ ) to collect much-needed revenue. Zimbabwean royalties, in particular, are significantly higher $\left(\mathrm{RTR}_{\text {Zimbabwe }}=1.00\right)$, indicating further revenue generation from the mining sector. While the DRC has one of the lowest royalty rates $\left(\mathrm{RTR}_{\mathrm{DRC}}=0.28\right)$, this is offset by the relatively high STR $_{\mathrm{DRC}}(1.00)$ and $\operatorname{ITR}_{\mathrm{DRC}}(0.80)$. Taxpayers in the DRC and Zimbabwe also experience considerable difficulty with application of and compliance with the local tax regulations. Being characterised as authoritarian states with the highest levels of corruption (The Economist, 2017; Transparency International $(2017 \mathrm{a}, \mathrm{b})$, there appears to be little emphasis on administration of the tax system and taxpayer rights $\left(\mathrm{TDR}_{\mathrm{DRC}}=0.95 ; \mathrm{TDR}_{\text {Zimbabwe }}=0.75\right)$ which are features of the South African and Botswanan tax regimes. 
Countries in Quadrant 3 are also classified as authoritarian states but report some of the lowest income tax rates in the 19 jurisdictions $\left(\mathrm{ITR}_{\text {Algeria }}=0.51 ; \mathrm{ITR}_{\text {Angola }}=0.67\right)$ and belowaverage RTRs $\left(\operatorname{RTR}_{\text {Algeria }}=0.47 ; \operatorname{RTR}_{\text {Angola }}=0.44\right)$. Unlike Zimbabwe and the DRC, the TDR of Angola is relatively low $\left(\mathrm{TDR}_{\text {Angola }}=0.54\right)$, suggesting that the tax system is more efficiently and effectively administered than in the countries in Quadrant 4. Algeria's tax system appears to be more efficient than the DRC's $\left(\mathrm{TDR}_{\text {Algeria }}=0.83 ; \mathrm{TDR}_{\mathrm{DRC}}=0.95\right) \mathrm{but}$ less efficient than Zimbabwe's $\left(\mathrm{TDR}_{\text {Zimbabwe }}=0.75\right)$. Nevertheless, the TDR scores for countries in Quadrant 3 are materially higher than those in Quadrant 1 and the average TDR scores for Quadrant 3 (0.69) and Quadrant 4 (0.85) show that they present a challenging tax environment for mining operations. This suggests that inefficiencies in the tax system may be a characteristic of authoritarian rule. Authoritarianism does not, however, result in a consistent TTB. In addition, differences in the perceived level of corruption cannot account for the variation in TTBs between Quadrant 3 and Quadrant $4\left(\mathrm{TTB}_{\mathrm{Q} 4 \text { Average }}=0.76 ; \mathrm{TTB}_{\mathrm{Q} 3 \text { Average }}=0.61\right)$. The corruption indices for Angola $(\mathrm{CI}=18)$, Algeria $(\mathrm{CI}=34)$, Zimbabwe $(\mathrm{CI}=22)$ and the DRC $(\mathrm{CI}=21)$ indicate that they rank among jurisdictions with the highest perceived levels of corruption in the world (Transparency International, $2017 a, b)$. What is different is the level of dependency on the mining sector. The Angolan and Algerian economies are relatively less reliant on mining than the DRC and Zimbabwe (Ericsson \& Löf, 2017). As a result, these authoritarian regimes do not require high taxes to extract value from the sector and bolster state coffers.

That authoritarian states do not consistently suffer from the highest tax burden is confirmed by the high ITRs $\left(\right.$ ITR $_{\text {Namibia }}=$ 1.00; $\left.\operatorname{ITR}_{\text {Senegal }}=0.80\right)$ and above-average RTRs $\left(\operatorname{RTR}_{\text {Namibia }}=\right.$ $0.75 ; \operatorname{RTR}_{\text {Senegal }}=0.53$ ) for Namibia and Senegal. These flawed democracies also report mixed TDRs $\left(\mathrm{TDR}_{\text {Namibia }}=0.42\right.$; $\left.\mathrm{TDR}_{\text {Senegal }}=0.94\right)$ despite the fact that, on average, the countries in Quadrant $1\left(\mathrm{CI}_{\text {Average }}=48.50\right)$ and Quadrant 2 $\left(\mathrm{CI}_{\text {Average }}=52.50\right)$ have similar corruption indices. Like South Africa and Botswana, the mining sectors in Senegal and Namibia make a significant contribution to GDP and export revenues (Ericsson \& Löf, 2017) that would account for the high ITR and RTR scores. The countries in Quadrant 1 are also less industrially developed than those in Quadrant 2 (World Economic Forum, 2017). As a result, financing public goods and services is more challenging and this explains the different TTB's in Quadrant 1 and Quadrant 2.

The high TTB for Senegal and Namibia should also be contrasted with those reported for countries in Quadrant 4. Like those in Quadrant 1, these jurisdictions are dependent on the mining sector for revenue, and therefore, operate tax regimes characterised by high-income taxes and royalty charges. Tax collection should, however, be interpreted in the context of significantly higher corruption indices (CI Quadrant $1=48.50$; CI Quadrant $4=21.50$ ) and overall administrative burden (TDR Quadrant $1=0.68$; TDR Quadrant $4=0.85$ ). When it comes to emerging economies that are flawed democracies, taxes are being collected to fund institutions that provide essential goods and services to citizens (see Hausken, Martin, \& Plümper, 2004). For authoritarian regimes it is not always clear how tax revenues are being utilised, but what is certain is that there is little investment in public welfare and the mechanisms of democracy (Hausken et al., 2004).

\section{Discussion, conclusion and implications}

This research explores the interconnection between the strength of democratic systems, levels of corruption and the burden imposed on taxpayers in the mining industry of 19 African countries with material mining operations. In line with earlier research, the results suggest that, on average, weaknesses in democratic systems, processes and institutions go hand in hand with higher levels of corruption (Kubbe \& Engelbert, 2018; Transparency International, 2017a,b). Based on the available data, a causal relationship cannot, however, be established.

The interconnection between the tax burden, the strength of democracy and levels of corruption is more surprising. Some of the most authoritarian regimes report the lowest tax rates, while democracies have some of the highest tax rates. There is also no indication that regimes characterised by higher levels of corruption also levy taxes at a higher rate. Final results are summarised in Figure 3 which shows the elements of and final TTB for the four flawed democracies and four authoritarian regimes. The relative levels of corruption and dependence on the mining sector (as per Ericsson \& Löf, 2017) are also indicated.

There are a number of important inferences. Firstly, in theory, authoritarian regimes should be able to charge more tax than democracies. They can increase tax rates and widen the scope of the tax net as required with little risk of an inherently unfair tax system leading to election defeat or being overturned by an independent judiciary. In contrast, a democratically elected government is more constrained when it comes to developing and applying tax policy. In practice, flawed democracies levy both income taxes (average ITR $=0.84$ ) and royalties (Average RTR $=0.61$ ) at a higher rate than authoritarian regimes (Averages: $\mathrm{ITR}=0.67 ; \mathrm{RTR}=0.55$ ). This means that more democratic states are just as capable of collecting tax revenues as dictatorships and that a democratic political system does not equate automatically with a lower tax charge (Cheibub, 1998).

In the absence of the mechanisms and institutions that safeguard citizens' rights and the need to invest in social and political welfare, authoritarian regimes avoid many of the costs which must be incurred by democratic states. They may have higher levels of corruption but they are not subject to the same level of public and political pressure to recover lost resources as is the case when stronger democratic systems are in place. Even after accounting for the preferential 


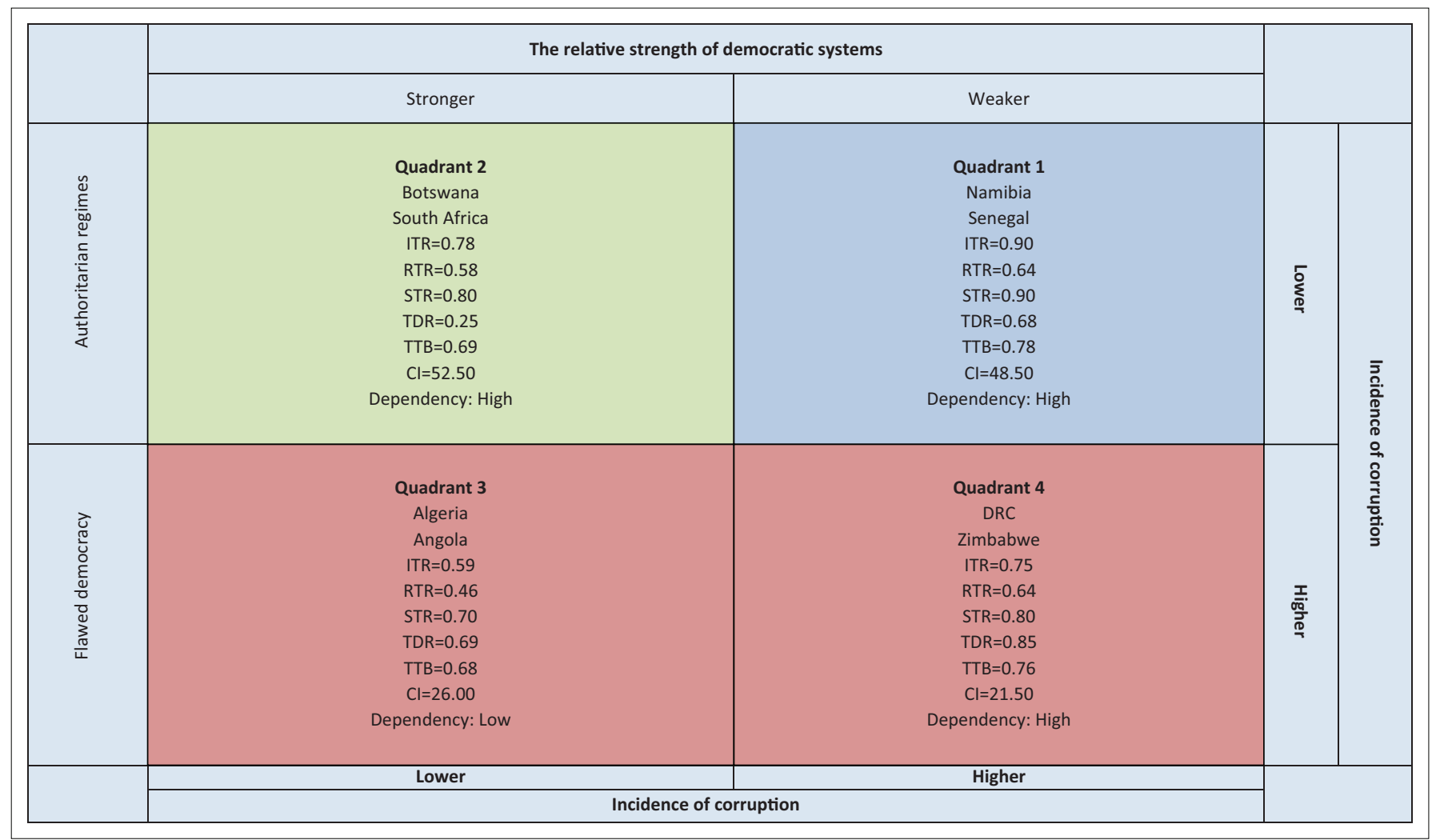

ITR, income tax ratio; RTR, royalty tax ratio; STR, supplementary tax ratio; TDR, tax difficulty ratio; TTB, total tax burden.

FIGURE 3: Tax burden, political system, level of corruption and dependence on mining.

treatment of the political elite, they have fewer demands on their budgets allowing them to charge taxes at lower rates. At the same time, dictatorships cannot continue indefinitely without any public support. Lower tax rates can substitute for the democratic values that may otherwise be used to appeal to the general public, investors and asset owners.

Secondly, a country's dependence on the mining sector for government revenue may be more important for predicting tax levels than the incidence of corruption or political system. For example, authoritarian regimes in Quadrants 3 and 4 have similar levels of corruption and weak democratic systems compared with jurisdictions in Quadrants 1 and 2. A key difference is the level of dependence on the mining sector. Algeria and Angola are among the countries where mining makes the lowest contribution to export revenues and GDP of the 19 countries under review. As a result, the average ITR and RTR for Quadrant $3\left(\mathrm{ITR}_{3}=0.59 ; \mathrm{RTR}_{3}=\right.$ $0.46)$ is lower than Quadrant $4\left(\mathrm{ITR}_{4}=0.75 ; \mathrm{RTR}_{4}=0.64\right)$. Similarly, countries in Quadrants 1 and 2 are heavily dependent on mining (Ericsson \& Löf, 2017) and charge the highest income tax and royalty rates notwithstanding the fact they have stronger democratic systems and lower levels of corruption than those in Quadrants 3 and 4.

Thirdly, a higher STR and TDR appear to offset the effect of a lower ITR and RTR in authoritarian regimes. The net result is that the average tax burden for flawed democracies (average $\mathrm{TTB}=0.69$ ) and authoritarian regimes is similar (average $\mathrm{TTB}=0.68)$. Where democratic values are espoused, the importance of charging a fair rate of tax and ensuring a reasonable administrative load is essential (see Vivian, 2006). Consequently, while flawed democracies must charge taxpayers more to support legitimate government operations, they take measures to ensure that tax systems are relatively efficient and to promote certainty when dealing with the local tax authority. In contrast, authoritarian regimes have little incentive to reduce taxpayers' administrative loads. It is also possible that inefficiencies in the tax system are used to frustrate taxpayers, discourage lobbying for lower taxes and levy additional charges implicitly.

Fourthly, the hybrid governments shown in Figure 2 can be seen as countries in a process of transition. Those with high tax rates, low levels of corruption and good governance systems in place have the potential to move into Quadrant 1. In this case, taxpayers will need to contribute to the socioeconomic development of these countries but according to a tax regime which is administratively sound and procedurally fairer. For others, there is a risk that weakening institutions of democracy will undermine civil rights. Where this occurs, governance systems break down and corruption becomes more common. Tax rates may fall but administrative costs will rise, while tax revenues will not necessarily be collected for the public good.

These findings have important implications for practice. They show that companies should be assessing the strength of democratic systems and perceived levels of corruption in the countries in which they do business. This is necessary for 
managing operating, financial and reputational risks. Where systems of democracy and governance are failing, it is also likely that compliance with and practical application of tax laws will become increasingly difficult and costly. From a different perspective, companies are coming under increasing pressure to show that they are good corporate citizens (Brookings Institution, 2016; Dyreng, Hoopes, \& Wilde, 2015; Flint \& Maignan, 2014), something which requires compliance with local regulations and paying a fair share of tax (Dyreng et al., 2015; Hardyment, Truesdale, \& Tuffrey, 2011; Muller \& Kolk, 2012). In this context, understanding where taxes are being paid and whether or not the collecting state is a legitimate democracy should be taken into account for the purpose of managing reputation risk and informing policy on where to do business.

Finally, this research provides evidence to suggest that antidemocratic behaviour and high levels of corruption can increase the total tax load. The results are relevant for economists and analysts interested in understanding the total cost and incidence of tax in the international capital market. To this end, additional research will be required. This article is limited to only 19 African states and relies on a single measure of political systems and perceived levels of corruption. A more extensive econometric analysis is needed which covers all African jurisdictions over an extended period and incorporates alternate indices to corroborate findings. As part of this, additional controls should be considered. The relevance of state dependence on the mining sector has been covered but other variables may also be contributing to differences in the TTB. Possible examples include levels of international investment, market efficiency and industry concentration. Each of these will need to be taken into account to develop a more refined model for explaining variations in the development and application of tax regulation in Africa.

\section{Acknowledgements}

The authors are grateful to Lelys Maddock, Robert Garnett and Alwyn De Koker for comments on earlier versions of this article.

\section{Competing interests}

The authors have declared that no competing interests exist.

\section{Authors' contributions}

W.M. conceptualised the article and was responsible for the literature review, method and results. A.J.R. and M.K. performed all data capturing, peer-reviewed the article and assisted with the conclusion and processing changes required by the reviewers.

\section{Funding information}

This research received no specific grant from any funding agency in the public, commercial or not-for-profit sectors.

\section{Data availability statement}

Data sharing is not applicable to this article as no new data were created or analysed in this study.

\section{Disclaimer}

The views and opinions expressed in this article are those of the authors and do not necessarily reflect the official policy or position of any affiliated agency of the authors.

\section{References}

Akafia, M.E., Kuenyehia, K., \& Kuenyehia, S. (2019). Mining: Ghana. Getting the Deal Through. Retrieved from https://gettingthedealthrough.com/area/22/ jurisdiction/134/mining-ghana/.

Alokolaro, O., \& Ukwuoma, G. (2016). Mining-Nigeria. The Law Reviews. Retrieved from http://thelawreviews.co.uk/edition/the-mining-law-review-edition-5/1140359/ mining-nigeria.

Armstrong, P., Segal, N., \& Davis, B. (2005). Corporate governance: South Africa, a pioneer in Africa. Retrieved from https://www.africaportal.org/publications/ corporate-governance-south-africa-a-pioneer-in-africa/.

Atkins, J., \& Maroun, W. (2015). Integrated reporting in South Africa in 2012: Perspectives from South African institutional investors. Meditari Accountancy Research, 23(2), 197-221. https://doi.org/10.1108/MEDAR-07-2014-0047

Brennan, N.M., \& Solomon, J. (2008). Corporate governance, accountability and mechanisms of accountability: An overview. Accounting, Auditing \& Accountability Journal, 21(7), 885-906. https://doi.org/10.1108/09513570810907401

Brookings Institution. (2016). The revival of corporate social responsibility. Brookings Institution. Retrieved from https://www.brookings.edu/wp-content/uploads/ 2016/07/marketforvirtue_chapter.pdf.

Calame, M. (2015). Burkina Faso mining tax alert. EY. Retrieved from http://www. ey.com/Publication/vwLUAssets/EY-mining-tax-alert-burkina-faso-august2015/\$File/ey-mining-tax-alert-burkina-faso-august-2015.pdf.

Carels, C., Maroun, W., \& Padia, N. (2013). Integrated reporting in the South African mining sector. Corporate Ownership and Control, 11(1), 991-1005. https://doi. org/10.22495/cocv11i1c11p6

Center for Systemic Peace. (2016). The polity project. Retrieved from http://www. systemicpeace.org/polityproject.html

Chamber of Mines. (2017). Mining tax regime. Chamber of Mines. Retrieved from http://www.chamberofmines.org.na/index.php/mining-tax-regime/

Chatham House. (2017). Democracy and elections in sub-Saharan Africa: Lessons learned from 2016 and what to expect in 2017. Chatham House. Retrieved from https://www.chathamhouse.org/sites/files/chathamhouse/events/special/201701-30-Africa-Transcript-Democracy $\% 20$ and $\% 20$ Elections $\% 20$ in $\% 20$ SubSaharan\%20Africa.pdf

Cheibub, J.A. (1998). Political regimes and the extractive capacity of governments: Taxation in democracies and dictatorships. World Politics, 50(3), 349-376. https:// doi.org/10.1017/S0043887100012843

Cheibub, J.A., Gandhi, J., \& Vreeland, J.R. (2010). Democracy and dictatorship revisited. Public Choice, 143(1-2), 67-101. https://doi.org/10.1007/s11127-0099491-2

Coimbra, C., Daniel, G., Fialho, J.A., \& Frias, M. (2017). Mining: Mozambique. Getting the Deal Through. Retrieved from https://gettingthedealthrough.com/area/22/ jurisdiction/137/mining-mozambique/.

Crowe Horwath. (2016). Africa tax facts guide 2016. Crowe Horwath. Retrieved from https://www.crowe.com/fr/ficorec/-/media/Crowe/Firms/Europe/fr/Ficorec/ files/Africa-Tax-Facts-Guide-20161-1.pdf?la=fr-FR\&modified $=20181031172926 \&$ hash=526C7CEA82CAA0B6985965711DEDD8372CEDE481.

De Schoutheete, A., Hollanders, T., \& Jannone, G. (2016). Mining - Democratic Republic of Congo. The Laws Review. Retrieved from https://thelawreviews.co.uk/ edition/the-mining-law-review-edition-8/1209358/democratic-republic-of-thecongo.

Deloitte. (2017). Algerian tax highlights. Deloitte. Retrieved from https://www2. deloitte.com/content/dam/Deloitte/global/Documents/Tax/dttl-taxalgeriahighlights-2017.pdf.

Deloitte. (2018). Guide to fiscal information - Key economies in Africa 2018. Deloitte. Retrieved from https://www2.deloitte.com/za/en/pages/tax/articles/guide-tofiscal-information-key-economies-in-africa-2018.html.

Dyreng, S.D., Hoopes, J.L., \& Wilde, J.H. (2015). Public pressure and corporate tax behavior. Journal of Accounting Research, 54, 147-186. https://doi. org/10.1111/1475-679X.12101

Ehrhart, H. (2011). Assessing the relationship between democracy and domestic taxes in developing countries. Retrieved from https://halshs.archives-ouvertes.fr/ halshs-00553607/document.

Elgood, T., Paroissien, I., \& Quimby, L. (2004). Tax risk management guide. PwC. Retrieved from https://www.pwc.com/gx/en/tax-management-strategy/pdf/taxrisk-management-guide.pdf. 
Ericsson, M., \& Löf, O. (2017). Mining's contribution to low- and middle-income economies. United Nations University World Institute for Development Economics Research. Retrieved from https://www.wider.unu.edu/sites/default/files/ Research. Retrieved from https://www.wider.
Publications/Working-paper/PDF/wp2017-148.pdf.

Extractive Industries Transparency Initiative. (2009). Advancing the EITI in the mining sector: A consultation with stakeholders. Extractive Industries Transparency Initiative. Retrieved from https://eiti.org/sites/default/files/documents/MINING $\%$ 20Compressed.pdffpage $=28$

EY. (2017). Worldwide corporate tax guide 2017. EY. Retrieved from http://www.ey com/Publication/vwLUAssets/Worldwide Corporate Tax_Guide_2017/\$FILE/ Worldwide $\% 20$ Corporate $\% 20$ Tax $\% 20$ Guide $\% 202017$.pdf.

Fialho, J.A., \& Viana, A. (2017). Mining 2017 Angola. Getting the Deal Through Retrieved from https://gettingthedealthrough.com/area/22/jurisdiction/151/ mining-2017-angola/.

Finan, P., \& Fall, A. (2017). Senegal's new mining code: Following regional trends DLA Piper. Retrieved from https://www.dlapiper.com/ /media/Files/Insights/ Publications/2017/03/Senegal_Mining.PDF.

Flint, D.J., \& Maignan, I. (2014). The value of corporate citizenship to business customers: Research directions. New meanings for marketing in a new millennium (pp. 119-123). Retrieved from https://doi.org/10.1007/978-3-319-11927-4_36

Freeedom House. (2018). Freedom House Programs. Retrieved from https:// freedomhouse.org/programs

Gajigo, O., Mutambatsere, E., \& Ndiaye, G. (2012). Royalty rates in African mining revisited: Evidence from gold mining. African Development Bank. Retrieved from https://www.afdb.org/fileadmin/uploads/afdb/Documents/Publications/ https://www.afdb.org/fileadmin/uploads/afdb/Documents/Publications/ AEB $\% 20 \mathrm{VOL} \% 203 \% 201$ ssue $\% 206 \% 20$ avril $\% 202012$
3\%20lssue $\% 206 \% 20$ avril $\% 202012 \% 20$ bis_01.pdf

Graziosi, G.R., \& Laporte, B. (2015). Mining taxation: Modeling of five mining projects and sharing of the mining rent. International Monetary Fund. Retrieved from $\mathrm{https} / / / \mathrm{www}$.imf.org/external/pubs/ft/scr/2016/cr1684.pdf

Grose, A., \& Koryakovtseva, K. (2017). The official mining in Africa country investment guide. Global Business Reports. Retrieved from https://www.gbreports.com/ guide. Global Business Reports. Retrieved from https://www.gbreports.com/
publication/the-official-mining-in-africa-country-investment-guide-macig-2017.

Hardyment, R., Truesdale, P., \& Tuffrey, M. (2011). The implications for multinationals. Corporate Citizenship. Retrieved from https://corporate-citizenship.com/wpcontent/uploads/Tax-as-a-Corporate-Responsibility-Issue.pdf.

Hausken, K., Martin, C.W., \& Plümper, T. (2004). Government spending and taxation in democracies and autocracies. Constitutional Political Economy, 15, 239-259. Retrieved from https://doi.org/10.1023/B:COPE.0000040431.47529.58

Hollyer, J.R., \& Wantchekon, L. (2011). Corruption in autocracies. Princeton University. Retrieved from https://www.princeton.edu/ Iwantche/Corruption in_Autocracies.

Huňady, J., \& Orviská, M. (2015). The effect of corruption on tax revenue in OECD and Latin America countries. Theoretical and Practical Aspects of Public Finance, 1(1), 80.

Jetter, M., Agudelo, A.M., \& Hassan, A.R. (2015). The effect of democracy on corruption: Income is key. World Development, 74, 286-304. https://doi. org/10.1016/j.worlddev.2015.05.016

Johnson, C. (2014). Algeria: New mining law adopted. Retrieved from http://www.loc.gov/ law/foreign-news/article/algeria-new-mining-law-adopted/.

Kolstad, I., \& Wiig, A. (2016). Does democracy reduce corruption? Democratization 23(7), 1198-1215. https://doi.org/10.1080/13510347.2015.1071797

Kong, T.Y. (2004). Corruption and the effect of regime type: The case of Taiwan. New Political Economy, 9(3), 341-364. https://doi.org/10.1080/1356346042000257796

KPMG. (2014a). Democratic Republic of Congo: Country mining guide. KPMG. Retrieved from https://home.kpmg.com/xx/en/home/insights/2014/09/democratic-republic congo.html.

KPMG. (2014b). Ghana: Country mining guide. KPMG. Retrieved from https://home kpmg.com/xx/en/home/insights/2014/04/ghana-mining-guide.html.

KPMG. (2016). The Zimbabwe National Budget 2017. KPMG. Retrieved from https:// home.kpmg.com/content/dam/kpmg/xx/pdf/2016/12/tnf-zimbabwe-dec92016.pdf.

Kubbe, I., \& Engelbert, A. (2018). Corruption and the impact of democracy. Crime, Law and Social Change, 70(2), 175-178. https://doi.org/10.1007/s10611-017 $9732-0$

Laporte, B., De Quatrebarbes, C., \& Bouterige, Y. (2017). Mining taxation in Africa: The gold mining industry in 14 countries from 1980 to 2015. HAL. Retrieved from https://halshs.archives-ouvertes.fr/halshs-01545361/document.

Leedy, P.D., \& Ormrod, J.E. (2014). Practical research: Planning and design. Harlow: Pearson Education.

Liu, L., \& Altshuler, R. (2013). Measuring the tax burden of corporate income tax unde imperfect competition. National Tax Journal, 66(1), 215-238. Retrieved from https://www.ntanet.org/NTJ/66/1/ntj-v66n01p215-37-measuring-burdencorporate-income.pdf

Maendeleo Policy Forum. (2016). Elections in the sub-Saharan Africa: General trends challenges and opportunities. Maendeleo Policy Forum. Retrieved from http:// www.africa.undp.org/content/dam/rba/docs/Reports/undp-rba-maendeleoelections-subsahara-africa-2016.pdf

Maro, T. (2017). Mining: Tanzania. Getting the Deal Through. Retrieved from https:// gettingthedealthrough.com/area/22/jurisdiction/66/mining-tanzania/

Maroun, W., Turner, M., \& Sartorius, K. (2011). Does capital gains tax add to or detract from the fairness of the South African Tax system? South African Journal of Economic and Management Sciences, 14(4), 436-448. https://doi.org/10.4102/ sajems.v14i4.131
Mitchell, P. (2009). Taxation and investment issues in mining. Organisation for Economic Co-operation and Development. Retrieved from https://www.oecd. $\mathrm{org} / \mathrm{site} /$ devaeo10/44282904.pdf

Mkandawire, T. (2010). On tax efforts and colonial heritage in Africa. Journal of Development Studies, 46(10), 1647-1669. https://doi.org/10.1080/00220388.20 10.500660

Mkokweza, C., Shandavu, N., \& Zulu, M.A. (2017). Mining: Zambia. Getting the Deal Through. Retrieved from https://gettingthedealthrough.com/area/22/jurisdiction/50/ mining-zambia/.

Monks, K. (2018). Why the wealth of Africa does not make Africans wealthy. CNN Retrieved from https://edition.cnn.com/2016/04/18/africa/looting-machinetom-burgis-africa/index.html.

Muller, A., \& Kolk, A. (2012). Responsible tax as corporate social responsibility: The case of multinational enterprises and effective tax in India. Business \& Society, 54(4), 435-463. https://doi.org/10.1177\%2F0007650312449989

Murphy, O. (2017). Articles: Tanzanian government increases mining royalties, takes $16 \%$ stake in projects and reviews mining agreements. BDO. Retrieved from https://www.bdo.co.za/en-za/insights/2017/tax/tanzanian-governmentincreases-mining-royalties-takes-16-stake-in-projects-and-reviews-miningagreements.

Norton Rose Fulbright. (2017). Senegal: A new mining decree to complete the 2016 mining code. Norton Rose Fulbright. Retrieved from http://www. nortonrosefulbright.com/files/senegal-a-new-mining-decree-to-complete-the2016-mining-code-149287.pdf.

Ntim, C.G., Opong, K.K., Danbolt, J., \& Thomas, D.A. (2012). Voluntary corporate governance disclosures by post-Apartheid South African corporations. Journal of
Applied Accounting Research, 13(2), 122-144. https://doi.org/10.1108/ 09675421211254830

Otto, J., \& Cordes, J. (2002). The regulation of mineral enterprises: A global perspective on economics, law and policy. Westminster: Rocky Mountain Mineral Law Foundation.

Otto, J., Andrews, C., Cawood, F., Doggett, M., Guj, P., Stermole, F., Stermole, J., \& Tilton, J. (2006). Mining royalties: A global study of their impact on investors, government, and civil society. The World Bank. Retrieved from http:// siteresources.worldbank.org/INTOGMC/Resources/336099-1156955107170/ miningroyaltiespublication.pdf

Patrick, S.M. (2012). Why natural resources are a curse on developing countries and how to fix it. The Atlantic. Retrieved from https://www.theatlantic.com/ international/archive/2012/04/why-natural-resources-are-a-curse-ondeveloping-countries-and-how-to-fix-it/256508/.

Pimenta, P., \& Cabeçadas, N. (2016). Mining - Mozambique. The Law Reviews. Retrieved from http://thelawreviews.co.uk/edition/the-mining-law-reviewedition-5/1140358/mining-mozambique.

PKF. (2017). Africa tax guide 2017-18. PKF. Retrieved from https://www.pkf.com/ media/10033655/pkf-africa-tax-guide-2017-2018-online.pdf.

PwC. (2017). Stop. Think... Act. Mine 2017. Retrieved from https://www.pwc.co.za/ en/assets/pdf/mine-2017.pdf

PwC. (2018). Paying taxes 2018. PwC. Retrieved from https://www.pwc.com/gx/en/ paying-taxes/pdf/pwc paying taxes 2018 full report.pdf?WT.mc id=CT13 paying-taxes/pdf/pwC_paying_taxes_2018_full_report.pdf?WT-me_id=C
PL1300-DM2-TR2-LS1-ND30-TTA4-CN_payingtaxes-2018-intro-pdf-button.

Rose-Ackerman, S. (2004). The challenge of poor governance and corruption. Copenhagen Consensus. Retrieved from http://www.copenhagenconsensus. com/sites/default/files/cp-corruptionfinished.pdf.

Segal, T.G., Segal, M., \& Maroun, W. (2017). The perceived relevance of tax riskmanagement in a South African context. Meditari Accountancy Research, 25(1) 82-94. https://doi.org/10.1108/MEDAR-01-2016-0008

Sipasi, O., \& Philip-Idiok, O. (2017). Mining: Nigeria. Getting the Deal Through Retrieved from https://gettingthedealthrough.com/area/22/jurisdiction/18/ mining-nigeria/.

Sousa, I., \& Moreira, H. (2016). Mining - Angola. The Law Review. Retrieved from http://thelawreviews.co.uk/edition/the-mining-law-review-edition-5/1140346/ mining-angola.

South African Revenue Service (SARS). (2016). Mineral and petroleum resources royalty. SARS. Retrieved from http://www.sars.gov.za/TaxTypes/MPRR/Pages/ default.aspx.

Stevens, C. (2017). Guide to mining regimes in Africa. LexAfrica. Retrieved from http:// www.lexafrica.com/wp-content/uploads/2016/09/LEX-Africa-Guide-to-miningin-Africa.pdf.

Sunley, E.M., \& Baunsgaard, T. (2001). The tax treatment of the mining sector: An IMF perspective. International Monetary Fund. Retrieved from http://siteresources. worldbank.org/INTOGMC/Resources/sunley-baunsgaard.pdf

Tamale and Co. Advocates. (2013). Mining in Uganda - Legal, tax \& investment climate. Tamale and Co. Advocates. Retrieved from http://www.tamaleadvocates. com/Mining $\% 20$ in $\% 20$ Uganda.pdf.

The Economist. (2017). Democracy Index 2017: Free speech under attack. The Economist Intelligence Unit. Retrieved from http://www.eiu.com/Handlers/ WhitepaperHandler.ashx?fi=Democracy_Index_2017.pdf\&mode=wp\&campaign d=Democracylndex 2017 .

The Economist. (2018). Democracy Index 2018: Me too? Political participation, protest and democracy. Retrieved from http://www.eiu.com/Handlers/White paperHandler.ashx?fi=Democracy_Index_2018.pdf\&mode=wp\&campaignid=De mocracy2018.

Transparency International. (2016). Corruption Perceptions Index: 2016. Transparency International. Retrieved from https://www.transparency.org/news/feature/ corruption_perceptions_index_2016. 
Transparency International. (2017a). Sub-Saharan Africa: Corruption is a big issue in 2016 African elections. Retrieved from https://www.transparency.org/news/ feature/africa_corruption is a big_issue in 2016 african_elections

Transparency International. (2017b). Corruption Perceptions Index 2017 shows high corruption burden in more than two-thirds of countries. Transparency International. Retrieved from https://www.transparency.org/news/pressrelease/ corruption_perceptions_index_2017_shows_high_corruption_burden_in_more than

Transparency International. (2018). Corruption Perception Index 2018. Retrieved from https://www.transparency.org/cpi2018

Treier, S., \& Jackman, S. (2008). Democracy as a latent variable. American Journal of Political Science, 52(1), 201-217. https://doi.org/10.1111/j.1540-5907.2007. 00308.x

Tsalik, S. (2004). Caspian Oil Windfalls: Who will benefit? Open Society Institute. Retrieved from https://www.opensocietyfoundations.org/sites/default/files/full_ report_0.pdf
Vivian, R. (2006). Equality and personal income tax: The classical economist and the Katz Commission. South African Journal of Economics, 74(1), 79-109. https://doi. org/10.1111/j.1813-6982.2006.00050.x

Wagner, R. (2016). Mining - Ivory Coast. The Law Reviews. Retrieved from http:// thelawreviews.co.uk/edition/the-mining-law-review-edition-5/1140355/miningivory-coast.

Woods, J., \& Lane, A. (2015). State of mining in Africa. Deloitte. Retrieved from https://www2.deloitte.com/content/dam/Deloitte/tr/Documents/energyresources/za-state-of-mining-africa-09022015.pdf.

World Economic Forum. (2017). The Africa competitiveness report 2017. World Economic Forum. Retrieved from http://www3.weforum.org/docs/WEF ACR_2017.pdf

Zaloznaya, M. (2015). Does authoritarianism breed corruption? Reconsidering the relationship between authoritarian governance and corrupt exchanges in bureaucracies. Law \& Social Inquiry, 40(2), 345-376. https://doi.org/10.1111/ Isi.12076 


\section{Appendix 1}

\section{Summary of mining taxes in select African countries.}

\section{Algeria}

The corporate income tax rate for mining companies is 19\% (Deloitte, 2017). Mining royalties are payable in addition to income tax with different rates applicable for solid combustibles and metallic minerals (1.5\%) and precious or semi-precious metals and gems (6\%) (Johnson, 2014).

\section{Angola}

The corporate income tax rate for mining companies in Angola is $25 \%$ (Fialho \& Viana, 2017; Stevens, 2017). A royalty regime is in place. The maximum rate of $5 \%$ applies to strategic minerals and stones. Construction materials of mining origin and other minerals not falling in a defined category attract royalties at the lowest rate (2\%) (Fialho \& Viana, 2017; Sousa \& Moreira, 2016).

\section{Benin}

Mining companies are taxed on income at a rate of $30 \%$ (Deloitte, 2018) and mining royalties are payable at $5 \%$ for precious stones, $2 \%$ for precious metals and 3\% for basic metals and other mineral substances (Stevens, 2017).

\section{Botswana}

Mining profits are taxed according to a formula resulting in a minimum tax charge of $22 \%$. The rate increases in proportion to the ratio of taxable income to gross income (Deloitte, 2018). Royalties are levied at 10\% (precious stones), 5\% (precious metals) or 3\% (other minerals) (Stevens, 2017).

\section{Burkina Faso}

The corporate income tax rate is $27.5 \%$ (Calame, 2015; Stevens, 2017). Royalties are charged at a rate of 3\% $-5 \%$ (Laporte, De Quatrebarbes, \& Bouterige, 2017).

\section{Côte d'Ivoire}

The corporate income tax rate is $25 \%$ (Deloitte, 2018). Gold attracts royalties at between $3 \%$ and $6 \%$, while other substances are subject to royalties of between $1 \%$ and $5 \%$ (Wagner, 2016).

\section{The Democratic Republic of Congo}

The corporate income tax rate is $30 \%$. Mining royalties are levied at $4 \%$ (for precious stones), $2.5 \%$ (for precious metals), $2 \%$ (for nonferrous metals), $1 \%$ (for coal) and $0.5 \%$ (for iron and other ferrous metals) (Deloitte, 2017b; De Schoutheete, Hollanders, \& Jannone, 2016; KPMG, 2014a).

\section{Ghana}

The corporate income tax rate is 35\% for mining companies (KPMG, 2014b; Akafia, Kuenyehia, \& Kuenyehia 2019). Royalties are charged at a fixed rate of $5 \%$ on revenue.

\section{Kenya}

Mining companies are taxed at 30\% unless they are a branch of a foreign company in which case the tax rate is 37.5\% (Deloitte, 2018). Mining royalties are payable. The maximum rate $(12 \%)$ applies to diamonds. Gemstones and other precious metals (such as gold and silver) are subject to royalties at $5 \%$. A rate of $8 \%$ applies to coal and the lowest rate $(1 \%)$ applies to industrial minerals (Stevens, 2017).

\section{Mali}

Mining companies are taxed at $25 \%$ and mining royalties are fixed at a rate of 3\% (Graziosi \& Laporte, 2015).

\section{Mozambique}

The corporate income tax rate is 32\% (Coimbra et al., 2017; Pimenta \& Cabeçadas, 2016) and a 20\% windfall profits tax is levied where the pre-corporate income tax net return is in excess of $18 \%$ (Coimbra et al., 2017). Mining royalties are payable at between $8 \%$ (for diamonds) and $1.5 \%$ (sands and stone) (Coimbra et al., 2017; Pimenta \& Cabeçadas, 2016). Precious metals and stones (other than diamonds) are taxed at 6\%, while coal and other minerals are taxed at 3\% (Coimbra et al., 2017; Pimenta \& Cabeçadas, 2016). 


\section{Namibia}

Mining companies are subject to income tax at 37.5\% except for diamond mining that is taxed at 55\% (Chamber of Mines, 2017; Deloitte, 2018). As with other African states, royalty taxes are levied at between $10 \%$ (rough diamonds, emeralds, rubies and sapphires) and $2 \%$ (semiprecious stones, non-nuclear fuel materials and industrial minerals) (Chamber of Mines, 2017; Deloitte, 2018). Metals are taxed at 3\% (Chamber of Mines, 2017; Deloitte, 2018).

\section{Nigeria}

The corporate tax rate for mining companies is $30 \%$, but an additional education tax of $2 \%$ is also payable (Alokolaro \& Ukwuoma, 2016; Sipasi \& Philip-Idiok, 2017). Mining Royalties are levied at 3\%-5\% of the value of minerals extracted (Sipasi \& Philip-Idiok, 2017).

\section{Senegal}

The rate of corporate income tax is 30\% (Deloitte, 2018). Mining royalties are levied between 2\% and 5\% (Finan \& Fall, 2017; Norton Rose Fulbright, 2017).

\section{South Africa}

Mining companies are taxed at a rate of $28 \%$. The royalty rate applied to each mineral is determined according to a formula, with the range as follows:

- for refined mineral resources: $0.5 \%$ to a maximum of $5 \%$,

- for unrefined mineral resources: $0.5 \%$ to a maximum of $7 \%$ (South African Revenue Service [SARS], 2016).

\section{Tanzania}

Corporate tax is payable at a rate not exceeding 30\% (Maro, 2017). Mining royalties are charged at between 3\% and 6\% but an 'inspection fee' of $1 \%$ of the value of all mineral exports has also been imposed (Murphy, 2017).

\section{Uganda}

Mining company corporate tax ranges from $25 \%$ to $45 \%$ (Tamale and Co. Advocates, 2013). The rate is determined by applying a formula which results in a higher tax charge for companies with a higher 'chargeable income' to gross income ratio, similar to Botswana (Tamale and Co. Advocates, 2013). Royalties are imposed at 5\% (precious stones) or 3\% (for precious and base metals or ores) (Tamale and Co. Advocates, 2013).

\section{Zimbabwe}

Mining companies are taxed at a rate of $25.75 \%$, including an AIDS levy (Deloitte, 2018). Mining royalties are charged. The maximum rate applies to diamonds (15\%), while the lowest rate is levied on coal (1\%) (KPMG, 2016). A rate of 10\% applies to platinum and precious stones, while 5\% applies to gold (KPMG, 2016) and 4\% to copper. Other precious metals are taxed at 4\% (KPMG, 2016).

\section{Zambia}

Corporate income tax is levied at 35\% for mineral processing companies and 30\% for mining operations (Deloitte, 2018; Mkokweza, Shandavu \& Zulu, 2017). Variable profit tax is payable on income earned from mining operations at $15 \%$ when taxable income exceeds $8 \%$ on the gross sales (Deloitte, 2018; Mkokweza et al., 2017). Mining royalties are payable at between 5\% and 6\% for most metals and minerals (Deloitte, 2018; Mkokweza et al., 2017). 